\title{
A Comparison of the Function of Leader-Member Exchange in Two Neighboring Farmer Groups in a Sandy Land Area in Yogyakarta Province, Indonesia
}

\author{
Alia Bihrajihant Raya ${ }^{1,2}$ \\ ${ }^{1}$ Department of Agriculture and Resource Economics, Graduate School of Agriculture and Life Sciences, The \\ University of Tokyo, 1-1-1 Yayoi, Bunkyo-ku, Tokyo, 113-8657, Japan \\ ${ }^{2}$ Department of Socio-economics of Agriculture, Faculty of Agriculture, Gadjah Mada University, Indonesia \\ Correspondence: Alia Bihrajihant Raya, Department of Socio-economics of Agriculture, Gadjah Mada \\ University, Jl Flora 1 Bulaksumur, Yogyakarta 55281, Indonesia. E-mail: dirayakan@faperta.ugm.ac.id
}

\author{
Received: January 8, 2014 Accepted: March 18, 2014 Online Published: May 26, 2014 \\ doi:10.5539/ass.v10n12p21 URL: http://dx.doi.org/10.5539/ass.v10n12p21
}

\begin{abstract}
Marginal land, unfertile soil, and an extreme climate are typical of a sandy land area. However, a group of farmers near the Indian Ocean of the Yogyakarta Province in Indonesia has successfully cultivated chili in such an area since 1985 using a new farming system. Two pioneering farmer groups in this sandy land area brought economic change to the farmers in this region by providing the technology of chili farming and collective marketing. This study aims to investigate the differences in the function of leader-member exchange in the farmer groups and its role in sustaining the farmer groups. This study focuses on the role of transformational leadership in functioning leader-member exchange, which is able to promote group satisfaction and commitment in order to improve group member behavior and group performance. We conclude that two different approaches sustain the performance of farmer groups. Farmer groups that have an official regular group meeting and groups that have transformational leadership by means of a leader-member exchange showed affected group performance. Otherwise, the performance of a farmer group that lacks a group meeting is built by members' individual motives, which are observed as an aggregation of group member behavior. Meanwhile, leader-member exchange affects commitment and becomes an importance aspect that influences group performance in both groups.
\end{abstract}

Keywords: farmer group, group member behavior, group performance, leader-member exchange, transformational leadership

\section{Introduction}

Since 1970, the Indonesian government has established farmer groups (FGs) to encourage farming development among farmers. Many programs have been established to enhance FG performance in order to strengthen the bargaining position of farmers by providing input subsidies and channeling capital. The program began with Bimbingan Massal: massive guidance, which was regulated with Presidential Decree No. 6/1969, until the regulatory Gabungan Kelompok Tani: FG union (GAPOKTAN) was created by Agriculture Minister Decree 93/Kpts/OT.210/3/1997. GAPOKTAN's goal was to unify FGs at the village level to be a union on a sub-district level and to encourage FGs to build a farm collective business.

Government effort has not resulted in improved performance of FGs for many reasons. Herman and Swastika (2011) demonstrated that some of the groups that were created by projects readily dissolved when the project was finished. Wahyuni (2003) declared that a group that was built based on the will of farmers in the community may face problems, such as the FG's board of directors being unable to lead. On the other hand, the FG leader is needed to sustain the FG by providing adequate access to credit, adequate access to cheap inputs, regulating group meetings, providing regular information about group meeting, direct marketing of products, organization of product price discrimination (Ofuoku \& Agbamu, 2013), and taking risks for the sake of the FG (Yunasaf, 2007). Moreover, a farmers' forum, which was held in Rome, Italy in 2010, highlighted the importance of leadership roles in farmer organization; leaders are important in order to reach goals of reducing poverty in developing countries (IFAD, 2010). 
Much of the research devoted to FGs has examined the power of leadership to enhance the performance of FGs. Many FG leaders drive the group only for outcome purposes (transactional obligations) (Ofuoku \& Agbamu, 2013) without considering spreading the group vision and values, norms, and motivations. Meanwhile, norm and legitimate consensus are principles for further developing FGs (Agriculture Minister Decree 273/Kpts/Ot.160/4/2007).

Distinct from transactional leadership, which only focuses on outcome, another paradigm of leadership, namely transformational leadership, should be introduced for leaders of FGs. This process is particularly relevant in communities that are based on a collective society (Bass, 1997). Furthermore, the leader of the FG should instill the behaviors of transformational leadership when communicating with the members of the FG. Leaders who embody the behaviors of transformational leadership can gather farmers into an environment of learning and cooperation in order to achieve a goal as a group (producing and marketing, for example). Furthermore, the function of transformational leadership can be catalyzed by the mechanism of exchange between the leader and members of the group-this process is called Leader-Member Exchange (LMX). In this study, the function of LMX is emphasized as an important aspect to analyze together with the behaviors of transformational leadership, rather than focusing only on transformational leadership. The characteristics of rural Java villagers whose still maintain strong mutual reciprocal relationships (Subejo, 2009) and the function of LMX, which is based on the mutual reciprocal influence (Howell \& Hall-Merenda, 1999), become predictors that LMX will be able to support the function of transformational leadership. Furthermore, it is also assumed that satisfaction and commitment ought to be mediators of transformational leadership and that LMX can affect performance.

\section{Literature Review and Research Framework}

Burns (1978) conceptualized leadership as either transactional or transformational (Bass \& Riggio, 2006). Transactional leadership emphasizes the transaction between leader and members, which is based on reaching a certain outcome. In this way, the leaders set the goals and provide the rewards when the goals are met. However, leaders somehow avoid responsibility, are absent when needed, and fail to follow up on members' requests (Nguni, 2011).

The theory of transformational leadership states that a capable leader can motivate members (Wang, Law, Hackett, \& Chen, 2005), inspire members to contribute more through the internalization of values (Givens, 2008), and encourage members to work beyond their own interests (Bass, 1995). Transformational leadership consists of four components: charismatic, inspirational, and intellectual stimulation and individualized consideration (Bass \& Avolio, 1994).

In leadership theory, the partnership between leader and members is based on a mutual reciprocal influence called LMX (Howell \& Hall-Merenda, 1999), which is able to support the function of transformational leadership. Day and Schyns (2010) state that in high-quality exchange relationships, agreements between the leader and members and consensus among members are related to organizational outcome. The quality of LMX can mediate the group's goals and satisfaction (Janssen \& van Yperen, 2004). However, Givens (2008) noted that several studies have indicated that transformational leadership impacts satisfaction.

Farmers want to satisfy needs that they cannot simply satisfy except via subscribing to such a farmer group; the group provides facilities that are only accessed through being a member of a FG (Ofuoku \& Agbamu, 2013). Satisfaction with the FG influences farmer participation while satisfaction could create strong social capital in the community and encourage members to help others (Ngaruko \& Lwezaula, 2013). Organ and Ryan (1995) cited in Fisher (2003) and Nguni, Sleegers \& Denesen (2006) found that satisfaction has a strong relationship to organizational citizenship behavior (OCB). In addition, Givens (2008) concluded that several research groups have found that OCB has a positive effect on performance.

Moreover, group identification fosters group collective action (de Weerd \& Klandermans, 1999), while commitment of the group become a potential moderating role between the relationship of transformational leadership and OCB (Nguni et al., 2006). According to Buchanan (1994) cited in Cook and Wall (1980), organizational commitment consists of two components: identification and loyalty. Identification refers to pride in an organization and internalization of the group's goals and values; loyalty is a sense of commitment to a group and a sense of belonging.

Previous research has shown that transformational leadership is directly linked to team performance (Balthazard et al., 2000; cited in Dione, Yammarino, Atwater, \& Spangler, 2004), whereas Dionne et al. (2004) found that the association between transformational leadership and team performance involves vision, commitment, environment, and conflict. In addition, Podsakoff, MacKenzie, Moorman \& Fetter (1990) described trust and satisfaction as potential moderators between transformational leadership and OCB. Wang et al. (2005) modeled 
the relationship between transformational leadership and group performance as being mediated by LMX and OCB. Howell and Hall-Merenda (1999) found that LMX, but not transformational leadership, was a significant predictor of follower performance. Janssen and van Yperen (2004) demonstrated that LMX has a positive effect on job satisfaction and Truckenbrodt (2000) found that the quality of LMX affects both a member's commitment and OCB. Moreover, the LMX has a significant influence on commitment (Truckenbroadt, 2000) and satisfaction (Volmer, Niessen, Spurk, Linz, \& Abele, 2011). Meanwhile, satisfaction and commitment are found to be a potential moderator in the relation between transformational leadership and group member behavior (Podsakoff et al., 1990).

Based on findings from previous research, we postulate that transformational leadership, which involves a leader's charisma, individualized consideration, inspirational, and intellectual stimulation, likely influences satisfaction and commitment in two ways, directly or indirectly through LMX. LMX is considered an important intermediate between transformational leadership and group member behavior and group performance. In addition, inserted satisfaction and commitment in the model are expected to influence group member behavior and performance either directly by transformational leadership or indirectly through LMX, as illustrated in Figure 1.

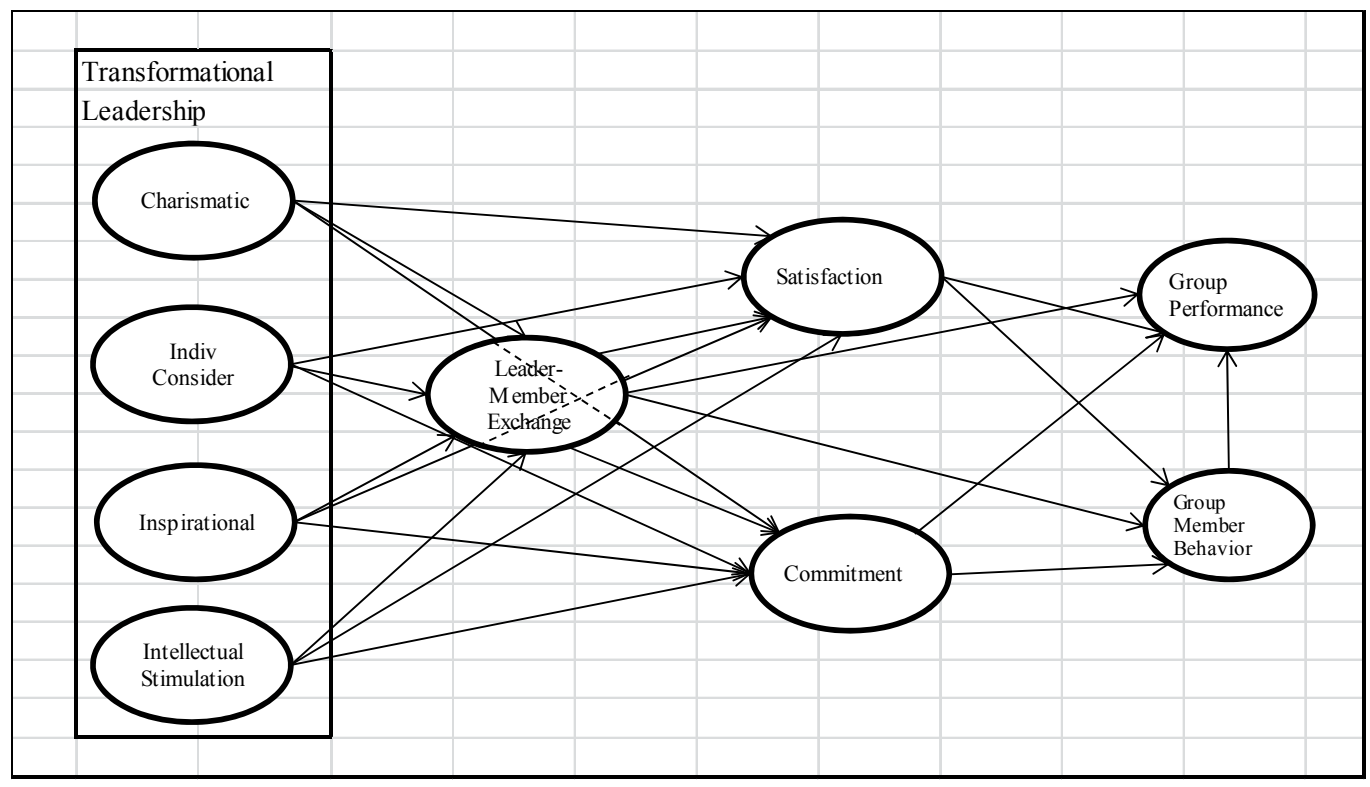

Figure 1. Research framework

This study pays attention to differences in characteristic FGs as reflections of different mechanisms used by the two pioneering FGs; this study was designed to compare several effects related to the two FGs, such as the attribution dimension of each mechanism and the direct effect among the dimension (the relationship between two dimensions on an arrow path and the indirect effect among the dimensions). The attribution dimension is a relationship between two dimensions that is intermediated by one or two dimensions in a path.

This study contributes to the FG performance and leadership literature in two respects. First, this study provides comparative empirical data for further discussion regarding transformational leadership, which is supported by the function of LMX on the FG performance and group member behavior. Second, this study is the first study to assess the function of transformational leadership, which is mediating by LMX, commitment, and satisfaction. Furthermore, this study is also the first study that is concerned with organization citizenship behavior (group member behavior) on the FG level.

\section{Material and Methods}

\subsection{Research Site}

The field research was performed in 2012 and included two FGs in a sandy land area in the Kulon Progo District of the Yogyakarta Province (Figure 2). The groups were located in the villages of Bugel and Garongan, which is where the chili FGs originated from. The distance between the two groups was approximately $5 \mathrm{~km}$ and both villages were located along the coastline of the Indian Ocean. The location was chosen based on the criterion of 
successful collective marketing.

The census method was used to obtain primary data regarding satisfaction, commitment, LMX, and transformational leadership from members of the Bugel and Garongan FGs. A total of 93 households (members) in Bugel and 85 households in Garongan were interviewed in-person. During each interview, a closed-structured questionnaire was used to assess LMX, transformational leadership, commitment, satisfaction, group performance, and group member behavior using a Likert scale ranging from 1 (strongly disagree) to 5 (strongly agree).

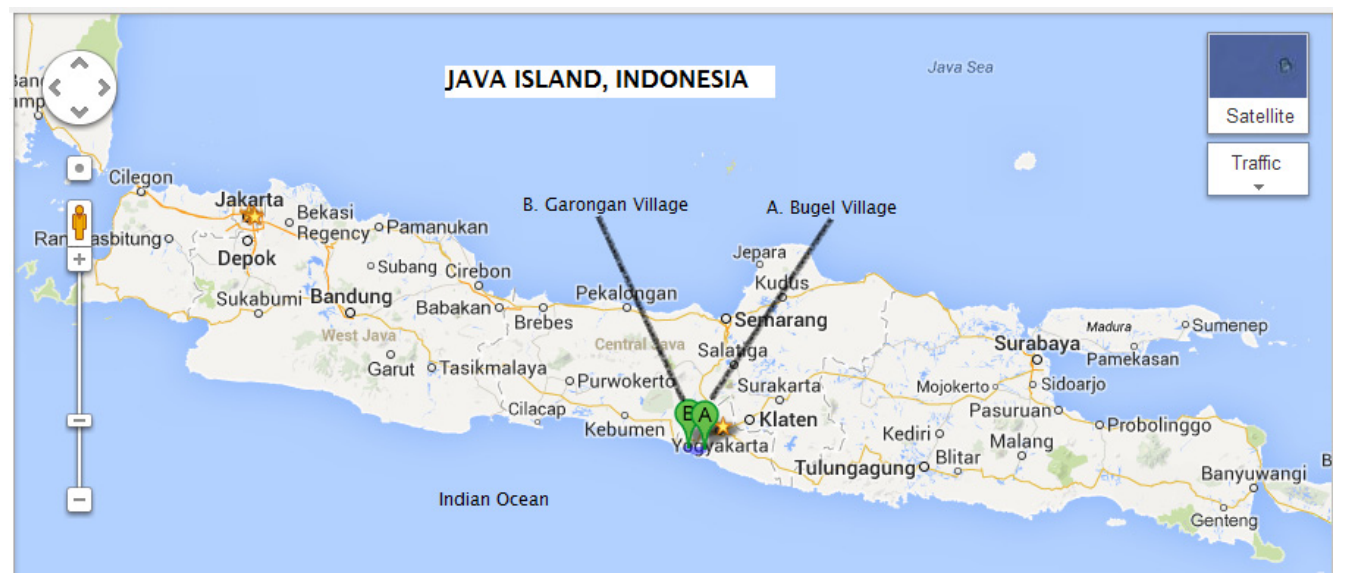

Figure 2. Map of the research site

\subsection{Data Analysis}

The data were analyzed by partial least squares (PLS) to determine which factors contributed most to the variables and which factors reflected the variable. PLS can be used as a structural equation model, based on variance, with small sample sizes (i.e., fewer than 100 samples) (Ghozali, 2011). PLS does not require assumptions about data distribution to estimate model parameters (Faulk \& Miller, 1992; cited in Howell \& Hall-Merenda, 1999). The path coefficients in PLS are standardized regression coefficients, while the loading of each item in the constructs is the factor loading.

The outer model was tested by calculating item reliability, internal consistency, and discriminant validity. Individual item reliability was examined using correlations between items and constructs, as shown in the loading factors. A reliable loading factor in PLS should be greater than 0.50 (Ghozali, 2011). The loading factors of indicators with values below 0.50 were excluded from the model and the model was iterated to obtain all reliable loading factors. The construct validity can be seen from the scale of average variance extracted, in which each variable should be above 0.50 . Reliability can also be examined through a construct's composite scale reliability, which measures internal consistency reliability and Cronbach's alpha (Ghozali, 2011). A construct is reliable when both the internal consistency reliabilities (IRCs) and Cronbach's alpha coefficient are above 0.70 (Nunnanly, 1978; cited in Howell \& Hall-Merenda, 1999).

The structural equation model was then used to examine the direct and indirect effects of dimensions. A direct effect was generated by the correlation between two dimensions directly, the value of which could be examined from coefficients along the path (Duncan, 1975). An indirect effect refers to the effect of two dimensions that pass through one or more dimensions. To obtain the value of an indirect effect, the path coefficients from each path are multiplied and then the products obtained for all linkages between dimensions are summed (Duncan, 1975).

\section{Results and Discussion}

\subsection{Historical Process of Farmer Groups}

Prior to 1970, farmers who lived in the coastal region in the Kulon Progo district, Yogyakarta Province utilized coastal sandy land in a limited manner. They only cultivated invaluable commodities such as cassava, peanuts, and corn for their own consumption during the rainy season. Only a few farmers who possessed an irrigated paddy field to cultivate paddies and chili alternatively could be prosperous. In 1980, a farmer in Bugel realized that chili could grow in sandy land during the rainy season and the dry season when water was available. This 
information spread to neighboring villages and vicinities. Beginning in 1985, two FGs (from the villages of Bugel and Garongan) tried to utilize sandy land by cultivating chili during both seasons. These FGs were created to support farmers after some farmers interested into chili farming found it difficult to work individually. The farmers should have prepared a well for watering, made a flatter area in the sandy land, and built a road for accessibility; those activities had to be performed with other people.

The farmers realized that the extreme climate and strong winds could cause disease and destroy the chili plants. Thus, according to the Javanese seasonal calendar, based on the direction of wind across the Indian Ocean (Pranata Mangsa), farmers believed that chili farming should be started on March 1. Interestingly, for chili farming, the timing of planting must be followed by all farmers; differing planting times can result in sanctions because the emergence of disease on one farm can attack plants on another farmer's land.

Farmers in Bugel formed a FG to share information and knowledge about how to cultivate chili in sandy land. The Bugel FG, which is called Gisik Pranaji, a name meaning "useful sandy land", was created in 1985. The leader of the Bugel FG was appointed in 1985 with no term limit. Thus, the leader has officiated for 28 years. The leader, who was an inventor of chili farming in sandy land areas, began leading the FG when he was 25 years old. The first activities of the FG included clearing and arranging the land, building a well, and preparing a farm road. Land clearing and arranging to flatten the mountainous sand were required before cultivation. Some members of the Bugel FG invented a new method of watering so the Bugel FG was known as sandy land farming innovators. These innovations were facilitated by networking between the FG's leader and university investigators who conducted research in Bugel's sandy land area.

The FG in Garongan is called Bangun Karyo, which means "work hard" and was founded in 1985. It managed the farmers based on the territory that covered four Rukun Tetangga or neighborhood associations consisting of 15-25 households. The Garongan FG was built to gather chili farmers implementing new farming systems on sandy land areas. Sandy land areas had been abandoned for many years. To utilize the land, the farmers needed to arrange the area. The FG conducted meetings to manage the landscape area, preparing it for chili farming.

The first leader of the Garongan FG led from 1985 to 1990. He was elected because he was an elder in the society. However, in 1990, he declined nomination as a leader again because he realized that a leader should be able to communicate with outsiders such as government officials in order to able to develop FG better economic conditions for the FG members. At that time, the member who had served as secretary from 1985-1990 was elected as the new leader and recently was elected for his fifth term.

The leader of the Garongan FG was involved in activities within and outside the group. Within the group, the leader conducted meetings for all members, met with the board members, made proposals to receive subsidized fertilizer, capital loans, and grants and solved problems that arose in the community. In order to deliver information quickly, Garongan's leader delegated neighborhood association heads to disseminate news to all of its members. Neighborhood association meetings were usually held every 35 days based on the Javanese lunar calendar, but there was a weekly meeting for religious activity as well, which the FG could use to disseminate urgent information.

Outside group activities varied and included networking with the chili trader, as well as the factory that provided seed, pesticide, and fertilizer. Other activities included participating in agricultural extension agent activities to maintain communication with the government to receive grants or loans. Because hybrid seed is expensive, the leader created a partnership with the seed factory to obtain a lower price through collective buying. Although the leader of the Bugel FG also coordinated seed collective buying, the distribution mechanism was different. The Garongan FG distributed seed packages based on the cultivated area of sandy land for each member (although the number of packages distributed was restricted due to the limited quantity of packages available). In contrast, the Bugel FG distributed seed packages based on the amount of funds kept in collective marketing during the previous year.

In Bugel, the trader treated input material and marketing product as a set. She supplied seed and fertilizer, which included subsidized fertilizer, during the harvesting period and she collected the farmers' chili products as well. Bugel's trader sold subsidized fertilizer to individual farmers whenever they needed it. In contrast, it was difficult for individual farmers in Garongan to obtain subsidized fertilizer, so that leader initiated a plan for the FG to provide subsidized fertilizer. The expectations of the Garongan village trader who provided input material were different than those of the Bugel trader. Bugel farmers who bought seeds with a debt were expected to sell a portion of their chili product in return. In Garongan, the seed trader and chili product trader were different individuals. Thus, Garongan farmers were not expected to sell a portion of the chili product to the trader to pay off their debt. 
Around 1997, farmers enjoyed a high price for chili, but some farmers could not maximize their benefit because some intermediate traders bought their products at lower prices than others did. This condition caused some friction among the farmers because the quality of the product was the same but the selling price differed. To set a consistent selling price, the farmers realized they needed to sell their chili collectively. In 2000, Garongan's leader mediated an agreement between the farmers and trader to arrange for the collective sale of the chili product at a standardized price. The Garongan FG invented collective marketing through an auction market mechanism. Then, the Bugel FG followed the collective marketing system, but the rules of collective marketing were slightly different for different members. The Garongan farmers determined the percentage of the total amount of chili product that should be sold through collective marketing to be a minimum of $80 \%$; the Bugel FG did not follow suit.

The Garongan FG has been conducting collective marketing for approximately 13 years; the Bugel FG has been doing the same for approximately 11 years. Currently, the chili collective marketing price for the FGs is competitive with the wholesale price. Competition among traders to obtain chili products has been high so traders tend to bid high to win an auction. According to the farmers, in 2012, the price of chili with collective marketing was approximately $12,000 \mathrm{IDR} / \mathrm{kg}$, whereas the individual selling price was approximately 9,000 IDR $/ \mathrm{kg}$ by traders. Although collective marketing always provided a higher price for chili product, the associated delay in payment became a crucial issue. Traders who won the bid did not pay cash immediately before transporting the chili product to the wholesaler in Jakarta or Sumatera. As a result, farmers had to wait 3 days or more to receive payment. The Garongan FG continued its practice of collective harvesting to economize the amount of wages to be paid, thus solving the delayed payment problem. In contrast, the Bugel FG permitted its members to get immediate cash by selling chili product individually to local traders.

\subsection{Attribution of Leadership and Group Dimensions}

There were nine dimensions to this study, which are reflected by the indicators. Most of the indicators are significant, but some are not significant. Here, we focus on the non-significant items to clarify the difference between the two FGs.

\section{a) Transformational leadership dimension}

As shown in Table 1, a difference in the willingness of the Bugel and Garongan leaders to take a personal risk on behalf of the group, an aspect of charisma, was noted; this indicator reflected the charismatic dimension of the Garongan FG's leader but not the Bugel FG's leader. With regard to risk-taking behavior on behalf of the group, the Garongan FG's leader was known as a negotiator who always sought a solution for group development. In this sense, his effort to negotiate was respected. He created networks between the FG and the seed factory and authorized subsidized fertilizer shops and chili traders. Sine a relationship had been established with these institutions, the FG was able to collectively obtain reasonably priced seed and subsidized fertilizer and enjoy collective marketing. Although the Bugel FG's leader initiated the same activities as the Garongan FG's leader, the mechanism of participation was different. The Bugel leader did not suggest that members join collectively; their participation was based on their willingness and many members decided to be responsible for their own choice so that the leader did not have to take a personal risk for them.

Inspirational motivation is a leadership behavior that motivates members by stressing important values in order to produce team spirit. Table 1 show that the leader of the Garongan FG tried to strengthen the group by encouraging members to obey the group's rules and develop the role of the FG to improve chili production. In contrast, the Bugel FG's leader sought to inspire every individual member to achieve good farm management by providing new technology and advising members when they faced a farming problem.

Table 1. Factor loadings of transformational leadership and IRCs

\begin{tabular}{lcc}
\hline Construct and Measure & \multicolumn{2}{c}{ Factor Loading/IRC } \\
Garongan & Bugel \\
\hline 1. Transformational Leadership & & $\mathbf{0 . 8 7}$ \\
(1.1) Charismatic & $\mathbf{0 . 9 3}$ & 0.74 \\
Ability of leader & 0.89 & 0.68 \\
Admiration toward leader & 0.87 & 0.77 \\
Role of decision making & 0.81 & $\mathrm{~ns}$ \\
Taking personal risks for the sake of group & 0.73 & \\
\hline
\end{tabular}




\begin{tabular}{llc}
\hline Construct and Measure & \multicolumn{2}{c}{ Factor Loading/IRC } \\
& Garongan & Bugel \\
\hline Personality of leader & 0.85 & 0.79 \\
Unifier of the FG & 0.84 & 0.79 \\
(1.2) Inspirational & $\mathbf{0 . 8 5}$ & $\mathbf{0 . 8 3}$ \\
Inspiration to develop the FG & 0.83 & 0.77 \\
Emphasizing the role of the FG & 0.72 & $\mathrm{~ns}$ \\
Emphasizing obeying the rules & 0.87 & $\mathrm{~ns}$ \\
Inspiring new technologies & $\mathrm{ns}$ & 0.77 \\
Making suggestions about farm problems & $\mathrm{ns}$ & 0.83 \\
(1.3) Intellectual Stimulation & $\mathbf{0 . 8 8}$ & $\mathbf{0 . 8 5}$ \\
Importance of group discussion & 0.84 \\
Disseminating new information & 0.85 & 0.52 \\
Encouraging new technologies & 0.85 & 0.80 \\
(1.4) Individual Consideration & 0.81 \\
Listening to members' problems & $\mathbf{0 . 8 0}$ \\
Personal communication & 0.67 & $\mathbf{0 . 8 5}$ \\
Feeling close to the leader & 0.68 & 0.68 \\
Personal suggestion & 0.77 & 0.69
\end{tabular}

Note: ns: not significant. Significant $\mathrm{p}<0.05$ and a bold score indicates an IRC

Source: primary data analysis using SmartPLS 2.0 M3, 2013

b) Group satisfaction dimension

Members tend to remain in a group when their needs are satisfied. The primary reason or need for joining a FG was to gain access to subsidized fertilizer because individual farmers could not access subsidized fertilizer. In addition, a FG was also a place to assemble to solve farm problems and standardize collective activities such as planting duration and collective marketing.

Table 2. Factor loadings of LMX, satisfaction, commitment, and IRCs

\begin{tabular}{llc}
\hline Construct and Measure & Factor Loading/IRC \\
& Garongan & Bugel \\
\hline (2.1) Leader-Member Exchange & $\mathbf{0 . 8 9}$ & $\mathbf{0 . 9 0}$ \\
I respect the leader's ability to guide this FG & 0.76 & 0.70 \\
I respect the leader's ideas to develop this FG & 0.74 & 0.72 \\
His kindness affects the group & 0.79 & 0.75 \\
The leader personality creates a good atmosphere in the FG & 0.71 & 0.67 \\
I will participate more actively in this FG & 0.70 \\
The FG emphasizes that my contribution is needed & 0.72 & 0.76 \\
I prefer to work together in this FG rather than farming individually & 0.74 \\
(2.2) Satisfaction & $\mathbf{0 . 8 9}$ & 0.53 \\
Satisfied with the rules of planting duration & 0.64 \\
Satisfied with the rules of selling at collective marketing & 0.66 \\
Satisfied with the FG's board work & 0.73 \\
Satisfied with the distribution of subsidized fertilizer & 0.70 \\
Satisfied with inputs and collective market information & 0.72 \\
Satisfied with the distribution mechanism =f seed collective buying & 0.77 \\
(2.3) Commitment & 0.76 & Ns \\
Identification-I'm proud to be member of this FG & $\mathbf{0 . 8 8}$ \\
Identification-Being an active participant is a source of pride for me & 0.70 \\
Identification-I feel a part of the FG & 0.79 & 0.65 \\
\hline
\end{tabular}




\begin{tabular}{llc}
\hline \multirow{2}{*}{ Construct and Measure } & \multicolumn{2}{c}{ Factor Loading/IRC } \\
& Garongan & Bugel \\
\hline Identification-I also help the group achieve its goals & 0.84 & 0.65 \\
Conformity-Becoming a member is the best plan & 0.65 & 0.74 \\
Conformity-I will do anything for this FG & 0.63 & 0.67 \\
Conformity-I will sell products through this FG, even without seed from the FG & $\mathrm{ns}$ & 0.77 \\
\hline
\end{tabular}

Note: ns: not significant. Significant $\mathrm{p}<0.05$ and a bold score indicates an IRC

Source: primary data analysis using SmartPLS 2.0 M3, 2013

Table 2 shows that the rule of selling through collective marketing did not significantly affect group satisfaction in the Bugel FG. Antecedent activity and distribution of seed collective buying, which would be expected to affect the collective marketing attitude, was not well regulated by the Bugel FG. Individual members could choose opportunistically to sell through collective marketing or to an individual trader. Satisfaction of the Bugel FG was not observed through a rule requiring collective selling; however, members could make use of both marketing channels opportunistically.

The government provided subsidized fertilizer, which could be accessed through an authorized subsidized fertilizer shop in the village. The method to redeem the subsidized fertilizer depended on the shop. Garongan members experienced some difficulty if they redeemed subsidized fertilizer individually because the shop processed the redemption of some members together. Thus, the Garongan FG effectively allowed the farmers to purchase subsidized fertilizer as a group. This mechanism did not occur with the Bugel FG because the authorized subsidized fertilizer shop in the Bugel village supported individual buying. According to Table 2, providing subsidized fertilizer at a group level to Bugel farmers did not affect group satisfaction because the mechanism did not exist. Members of the Bugel FG should buy subsidized fertilizer individually.

c) Commitment dimension

Farmers become engaged in a FG if they received the same opportunity that was provided by the group. The mechanism of seed distribution in the Bugel FG did not fulfill the needs of all of the members, whereas the Garongan FG attempted to distribute the seed evenly. Farmers were dependent on the trader or institution that provided the seed. Interestingly, members of the Bugel FG sold chili products through collective marketing even if they did not receive the seed from the group (Table 2). The Bugel system allowed members to make individual decisions regarding chili farming and marketing. Members of the Bugel FG who had off-farm jobs could choose to procure seed from the group or an outside trader. They could also create and maintain a relationship with the trader to obtain seed easily. With respect to marketing, the high price of chili product obtained through collective marketing lured member to sell chili through collective marketing.

In contrast, members of the Garongan FG remained in the group as long as the group provided common goods. Providing seed for members and collecting chili product were reciprocal activities that occurred between the Garongan FG and its members. Collective seed buying was regarded as Garongan FG's obligation to its members, while members regarded it as their obligation to sell chili product through collective marketing. If the system of collective seed buying disappeared, members of the Garongan FG no longer regarded it as their obligation to sell collectively and sold chili product to local traders freely, without considering the rule of a minimum percentage of selling.

d) Group performance and the group member behavior dimension

The five indicators of group performance consisted of: tangibility (infrastructure), reliability (the consistency of promised service), responsiveness, assurance, and empathy. Table 3 shows that only the empathy and tangible indicators of two FGs differed from each other.

Table 3. Factor loadings of group performance, group member behavior, and IRCs

\begin{tabular}{lc}
\hline Construct and Measure & $\begin{array}{c}\text { Factor Loading } \\
\text { Garongan }\end{array}$ \\
\hline (3.1) Group Performance & $\mathbf{0 . 9 5}$ \\
Assurance-Collective marketing can be trusted & 0.68 \\
Empathy-The FG board communicates with members & 0.59 \\
\hline
\end{tabular}




\begin{tabular}{lll}
\hline Construct and Measure & Factor Loading \\
& Garongan & Bugel \\
\hline Empathy-The FG board tries to fulfill members' needs & $\mathrm{ns}$ & 0.64 \\
Reliability-Provided seed by network with seed company & 0.77 & 0.51 \\
Reliability-Seed distribution & 0.82 & 0.58 \\
Responsiveness-Helping members & 0.77 & 0.77 \\
Responsiveness-Satisfying members & 0.79 & 0.77 \\
Tangibility-Facilitating obtaining subsidized fertilizer & 0.60 & $\mathrm{~ns}$ \\
Tangibility-Creating a simpler chili market & 0.75 & 0.52 \\
(3.2) Group Member Behavior & $\mathbf{0 . 8 2}$ & $\mathbf{0 . 7 8}$ \\
Ready to become bored a board member & 0.62 & 0.62 \\
Persuading other member to participate & 0.74 & 0.67 \\
Only selling chili through collective marketing & 0.65 & 0.65 \\
Ready to be a more active participant & 0.57 & 0.67 \\
Persuading others to sell only in the group & 0.68 & $\mathrm{~ns}$ \\
I always help others when needed & 0.67 & 0.59 \\
\hline
\end{tabular}

Note: ns: not significant. Significant $\mathrm{p}<0.05$ and a bold score indicates an IRC

Source: primary data analysis using SmartPLS 2.0 M3, 2013

Although the Garongan FG board worked hard to fulfill the members' needs for seed, the limited quota of seed from the distributor led to an insufficient quantity of seeds; the needs of all members could not be met. In contrast, the Bugel FG did not require members to contribute collectively at the group level. Members used their own judgment and were responsible for their own farming. However, the Bugel FG board did provide collective seed buying and marketing to help ease the needs of the farmers. Members of the Bugel FG were empathetic with the board because it provided services without requiring a minimum percentage of the product to be sold collectively. Ironically, the Garongan FG did not receive empathy from its members because the members were not satisfied with the amount of seed provided in light of their obligation to collectively market as much as $80 \%$ of their total chili product.

In terms of tangible indicators of group performance, the Garongan FG distributed the subsidized fertilizer instead of an authorized subsidized fertilizer shop. As a result, the Garongan FG developed a mechanism of channeling subsidized fertilizer. The Garongan FG members viewed the mechanism as a tangible support, allowing them access to subsidized fertilizer. In contrast, the Bugel FG did not need to provide subsidized fertilizer to its members because Bugel's authorized shop was able to supply subsidized fertilizer to the members individually. The Bugel members also preferred to purchase subsidized fertilizer directly in order to acquire other materials, such as chili seed. Providing subsidized fertilizer through the Bugel FG was not a tangible activity for members.

Group member behavior is adopted from OCB, which consists of informal contributions that members are able to make without considering rewards or sanctions. The different member behaviors between the two FGs can be explained by the requirement of one group to persuade its members to sell chili only through collective marketing (Table 1). As discussed above, members of both FGs understood that larger quantities of chili yielded a higher bid at auction in collective marketing. However, collective marketing is also associated with delayed payment, which can be a critical problem. Members of the Bugel FG allowed fellow members to sell individually to traders, recognizing that some farmers faced cash shortage problems to pay harvesting labor wages. Basically, each member of the Bugel FG expected others to sell through collective marketing because they understood that collective marking of the chili resulted in a higher price, but they also understood the need to have cash available to pay for harvesting labor and were thus understanding of members who sold chili to an individual trader.

\subsection{Direct Effects among the Dimensions}

LMX, satisfaction, and commitment are the potential intermediates from transformational leadership to group member behavior and group performance. An examination of the direct effect between the two dimensions identifies the different characteristics of the two FGs. 

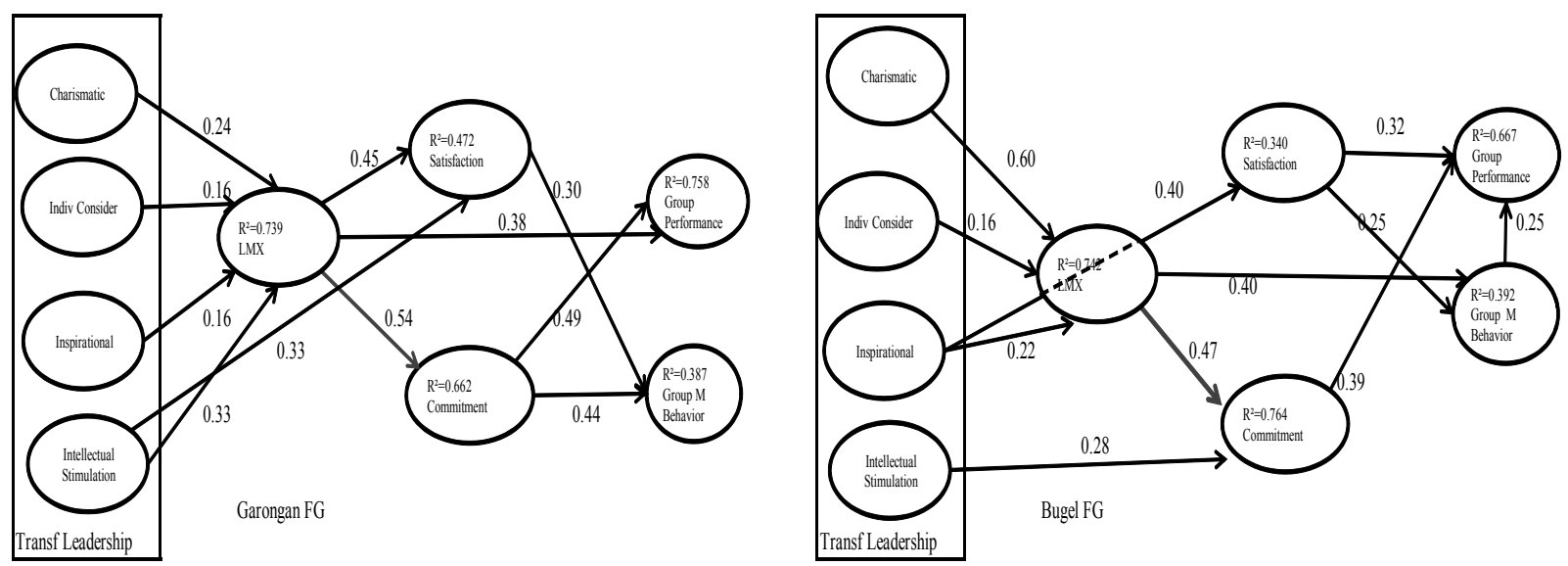

Figure 3. Direct effect of group performance and group member behavior

Calculated by Smart PLS 2.0 M3, 2013

According to Figure 3, for the Garongan FG, all of the transformational leader dimensions associated positively with LMX, whereas for the Bugel FG, only three dimensions-charismatic, individual consideration, and inspirational- showed a positive association with LMX. The systems of exchange between the leader and the members created by the two FGs were different. In the Garongan FG, as discussed above, regular, official meetings constituted the basis of the group collective activity. The group meetings functioned as the mode of communication between the leader and the members and created legitimate consensus at the group level. In Bugel, the FG did not select regular group meetings as a medium of exchange between the leader and members. The leader and members of the Bugel FG utilized the event of collective marketing to communicate regarding farming in personal or everyday life.

Moreover, the relationship between the leader and members can influence satisfaction and commitment. Regarding Figure 3, LMX in the Garongan FG influenced both satisfaction and commitment, whereas LMX in the Bugel FG only influenced commitment. However, Garongan's transformational leadership had only a direct effect on satisfaction; whereas Bugel's transformational leadership influenced both satisfaction and commitment directly. In this sense, the function of LMX in the Garongan FG had a larger effect on satisfaction and commitment than on interpersonal communication. For the Bugel FG, interpersonal communication had a greater effect on the relationship between the leader and members than the LMX. In the Garongan FG, LMX at the group level shared norms among member to respect collective activity so that members were satisfied with the group as it was. In the Bugel FG, LMX did not produce satisfaction because an interpersonal approach was more important than the collective approach.

For the Garongan FG, LMX directly affected group performance, whereas for the Bugel FG, LMX directly affected group member behavior, as illustrated in Figure 3. The Garongan FG implemented regular group meetings to discuss members' needs, enabling proper LMX. Members of the Garongan FG shared a legitimate group consensus such that the performance of members was likely regulated by consensus. Members always acted collectively to respect the consensus so that it influenced group performance directly. In contrast, LMX influenced group member behavior of the Bugel FG. Although LMX was organized at the group level, members could make use of the opportunity to communicate with the leader and board members in the event of collective marketing to receive information personally. Based on the information, members could decide for themselves whether to join the collective marketing.

In the Bugel FG, group performance could be observed through group member behavior. Group member behavior was established based on each member's individual judgment; almost all of the members decided to join collective marketing because they decided that it was beneficial. Group performance was observed as an aggregation of member behavior.

In addition, in the Bugel FG, group satisfaction affected both group member behavior and group performance, whereas in the Garongan FG, group satisfaction affected only group member behavior. The path from satisfaction to group member behavior involved first member satisfaction with individual merits achieved by the group and then member persuasion of other members to participate more actively in group activities. In the Bugel FG, 
members satisfied with some of the merits provided through the group, such as seed, information, and collective marketing, positively affected group performance. However, in the case of the Garongan FG, satisfaction was not sufficient to affect group performance because group performance was strongly influenced by other factors, such as LMX, without considering the satisfaction of obtaining incentives.

In contrast to the results observed for group satisfaction, the commitment of members in the Bugel FG affected only group performance. However, for the Garongan FG, member commitment affected both group performance and group member behavior. The members of the Garongan FG who committed to the group had two motivations: a feeling of obligation and individual merits. Because of the latter motivation, Garongan members attempted to persuade others to participate more actively while the obligation factor discussed above influenced group performance directly. In contrast, the Bugel farmers needed to be entitled as a member of the Bugel FG to enjoy input material and chili sales in order to be willing to maintain their member status and ultimately improve the group performance.

\subsection{Indirect Effect among the Dimensions}

Applying a structural equation model has revealed indirect effects useful for understanding the pattern to each dimension. The pattern of transformational leadership into group performance is most likely mediated by LMX, satisfaction, commitment, and group member behavior. Table 4 shows a significant indirect relationship between transformational leadership and group performance and between transformational leadership and group member behavior.

Table 4. Indirect effects between transformational leadership and group performance and group member behavior

\begin{tabular}{|c|c|c|}
\hline I. Path coefficient of indirect effect to group performance & Garongan & Bugel \\
\hline A. Transformational Leadership-> LMX-> Group Performance & 0.39 & ns \\
\hline A-1. Charismatic-> LMX-> Group Performance & 0.09 & ns \\
\hline A-2. Individual-> LMX-> Group Performance & 0.10 & ns \\
\hline A-3. Inspirational-> LMX-> Group Performance & 0.06 & ns \\
\hline A-4. Intellectual-> LMX-> Group Performance & 0.13 & ns \\
\hline B. Transformational Leadership-> Satisfaction- $>$ Group Performance & ns & 0.13 \\
\hline B-1. Inspirational-> Satisfaction-> Group Performance & ns & 0.13 \\
\hline C. Transformational Leadership-> Commitment-> Group Performance & ns & 0.11 \\
\hline C-1. Intellectual-> Commitment-> Group Performance & ns & 0.11 \\
\hline D. Transformational Leadership-> LMX-> Commitment-> Group Performance & 0.24 & 0.18 \\
\hline D-1. Charismatic-> LMX-> Commitment-> Group Performance & 0.06 & 0.11 \\
\hline D-2. Indiv Consider-> LMX-> Commitment-> Group Performance & 0.06 & 0.03 \\
\hline D-3. Inspirational-> LMX-> Commitment-> Group Performance & 0.04 & 0.04 \\
\hline D-4. Intellectual-> LMX-> Commitment-> Group Performance & 0.08 & ns \\
\hline E. Transformational Leadership-> LMX-> Group M Behavior-> Group Performance & ns & 0.10 \\
\hline E-1. Charismatic-> LMX-> Group Member Behavior-> Group Performance & ns & 0.06 \\
\hline E-2. Indiv Consider-> LMX-> Group Member Behavior-> Group Performance & ns & 0.02 \\
\hline E-3. Inspirational-> LMX-> Group Member Behavior-> Group Performance & ns & 0.02 \\
\hline F. Transformational Leadership- $>$ Satisfaction- $>$ Group Member Behavior- $>$ Group Performance & ns & 0.03 \\
\hline F-1. Inspirational- $>$ Satisfaction- $>$ Group Member Behavior- $>$ Group Performance & ns & 0.03 \\
\hline II. Path coefficient of indirect effect to group member behavior & Garongan & Bugel \\
\hline G. Transformational Leadership-> Satisfaction-> Group Member Behavior & 0.10 & ns \\
\hline G-1. Intellectual-> Satisfaction-> Group Member Behavior & 0.10 & ns \\
\hline H. Transformational Leadership-> LMX-> Commitment-> Group Member Behavior & 0.19 & ns \\
\hline H-1. Charismatic-> LMX-> Commitment-> Group Member Behavior & 0.05 & ns \\
\hline H-2. Indiv Consider-> LMX-> Commitment-> Group Member Behavior & 0.05 & ns \\
\hline H-3. Inspirational-> LMX-> Commitment-> Group Member Behavior & 0.03 & ns \\
\hline H-4. Intellectual-> LMX-> Commitment-> Group Member Behavior & 0.06 & ns \\
\hline I. Transformational Leadership-> LMX-> Satisfaction-> Group Member Behavior & 0.14 & ns \\
\hline
\end{tabular}




\begin{tabular}{lll}
\hline I. Path coefficient of indirect effect to group performance & Garongan & Bugel \\
\hline I-1. Charismatic-> LMX-> Satisfaction-> Group Member Behavior & 0.03 & $\mathrm{~ns}$ \\
I-2. Indiv Consider-> LMX-> Satisfaction-> Group Member Behavior & 0.04 & $\mathrm{~ns}$ \\
I-3. Inspirational-> LMX-> Satisfaction-> Group Member Behavior & 0.02 & $\mathrm{~ns}$ \\
I-4. Intellectual-> LMX-> Satisfaction-> Group Member Behavior & 0.05 & $\mathrm{~ns}$ \\
\hline
\end{tabular}

Note: A bold score is the total indirect effect score; the indirect effect of at least one significant result is shown. Significant $\mathrm{p}<0.05$.

Source: primary data analysis using SmartPLS 2.0 M3, 2013

Table 4 shows that charismatic, individual consideration, inspirational, and intellectual stimulation affect group performance, which is mediated by LMX. The leader of the Garongan FG had a functional LMX, which stressed the function of legitimate consensus for achieving group performance. In contrast, this pattern is not significant for the Bugel FG, which lacked regular group meetings and legitimate consensus and could not encourage members to contribute to group performance. However, Table 4 shows that for the Bugel FG, the existence of LMX, which was simultaneously influenced by the leader's charisma, individual consideration, and inspirational, was sufficient to establish group member behavior and affect group performance. The leader of the Bugel FG realized that his members were opportunistic, so, via LMX, the leader could help the members understand that they could receive more merits by participating as a group. As a result, members paid attention to the individual incentives, which influenced the group behavior. The Bugel member behavior brought advantages to the group, replacing the function of legitimated consensus so that behavior governed the group.

Both FGs established a pattern of transformational leadership to group performance, which was intermediated by LMX and commitment (Table 4). In the Garongan FG, the pathway utilizing LMX showed that member participation was based on a shared norm of legitimate consensus so that feelings of obligation or commitment influenced group performance. In contrast, members of the Bugel FG internalized the leader's ideas. As long as individuals remained members, they could enjoy the merits of group activities, such as collective seed buying and marketing; this situation preserved their commitment as members. They understood the benefit of access to group activity. As a result, the pattern of transformational leadership, which was intermediated by LMX and commitment, influenced group performance in the Bugel FG.

In addition, another pattern intermediated through LMX and commitment affected group member behavior in the Garongan FG because members were encouraged to make use of the merits available from participating in the group, such as access to stable seeds and subsidized fertilizer, a high chili price due to collective marketing, and innovative technology. As a result, the pattern of LMX and commitment influenced not only group performance but also group member behavior (Table 4).

Interestingly, in Garongan, the pattern of transformational leadership and LMX associated with satisfaction influenced only group member behavior (Table 4) and not group performance. In this FG, members abided by the rules regardless of personal satisfaction. When members realized that they could obtain personal merits by actively participating in a group, they were satisfied and tried to pursue collective behavior as a group member behavior. In addition, inspirational communication between the leader and members of the Garongan FG in daily life created satisfaction and influenced group member behavior (Table 4). According to Table 4, members of the Bugel FG who were satisfied with the economic merits provided by the FG were motivated to pursue individual incentives to participate in collective activities. Although transformational leadership in the Bugel FG did not influence group performance, it was intermediated by LMX. However, the inspirational behavior of the leader and the leader's intellectual stimulation had an indirect effect on group performance via satisfaction and commitment (Table 4). In Bugel, there were some patterns that did not include LMX, as shown in Table 4, suggesting that when the ability of LMX to achieve a legitimate consensus is weak, interpersonal communication can replace that function.

\section{Conclusions}

This study has addressed an important consideration when comparing of the function of LMX in two neighboring FGs in a sandy land area in Yogyakarta Province, Indonesia. The findings of this study have several intriguing managerial implications. First, LMX includes an important role in the leadership of FG to enhance group performance. Leaders and members that experience regular group meetings can meet the group consensus and obey the rules of FGs perfectly so that the personality of the leader and the exchange mechanism can influence the performance of the group. On the other hand, when the group lacks group meeting activities, the 
leader and members exchange information by introducing interpersonal relations. However, this mechanism enhances group membership behavior, which affects strong group member behavior, enabling good performance. This finding answered the problem of many FGs in Indonesia, which tend to have weak performance because of a lack of regular group meetings. The FG leader should possess behaviors that can be admired by members, provide inspiration, promote intellectual stimulation, and be considerate of member situations.

Second, the commitment of members can increase the performance of FGs. Members are able to performed well not only in groups with regular meeting but also in groups that lack meetings. In this sense, the leader of the FG should pay more attention to make members conform to the nature of the FG. Third, the leaders of FGs that lack group meetings also should consider member satisfaction because satisfied members will influence group performance.

The Indonesian government faces problems on sustaining FGs. Transformational leadership and LMX can be the important issues for developing FGs. Transactional leadership, paired with transformational leadership, can increase the sustainability of FGs.

\section{Acknowledgements}

The author would like to thank Professor Takenori Matsumoto, Department of Agriculture and Resource Economics, The University of Tokyo for his valuable comments and insightful reading of this manuscript. This study has been funded by the Directorate General of Higher Education (DGHE) Scholarship, Indonesia.

\section{References}

Bass, B. M. (1995). Theory of transformational leadership redux. Leadership Q., 6, 463-478. http://dx.doi.org/10.1016/1048-9843(95)90021-7

Bass, B. M. (1997). Does the transactional-transformational leadership paradigm transcend organizational and $\begin{array}{llll}\text { national boundaries? } & \text { American }\end{array}$ http://dx.doi.org/10.1037/0003-066X.52.2.130

Bass, B. M., \& Avolio, B. J. (1994). Improving organizational effectiveness through transformational leadership. London: SAGE Publications.

Bass, B. M., \& Riggio, R. E. (2006). Transformational leadership (2nd ed.). London: Lawrence Erlbaum Associates Publishers.

Cook, J., \& Wall, T. (1980). New work attitude measures of trust, organizational commitment and personal need non-fulfillment. J. Occup. Psychol., 53, 39-52. http://dx.doi.org/10.1111/j.2044-8325.1980.tb00005.x

Day, D. V., \& Schyns, B. (2010). The importance of agreement and consensus in leadership research: Introduction to the special issue. Eur. J. Work Org. Psychol., 19, 255-258. http://dx.doi.org/10.1080/13594320903448766

De Weerd, M., \& Klandermans, B. (1999). Group identification and political protest: Farmers' protest in Netherlands. Eur. J. Soc. Psychol., 29, 1073-1095. http://dx.doi.org/10.1002/(SICI)1099-0992(199912) 29:8<1073::AID-EJSP986>3.0.CO;2-K

Dionne, S. D., Yammarino, F. J., Atwater, L. E., \& Spangler, W. D. (2004). Transformational leadership and team performance. J. Organiz. Change Manage., 17, 177-193. http://dx.doi.org/10.1108/09534810410530601

Duncan, O. D. (1975). Introduction to Structural Equation Models. Academic Press, New York.

Fisher, C. D. (2003). Why do lay people believe that satisfaction and performance are correlated? Possible sources of a commonsense theory. J. Org. Behav., 24, 753-777. http://dx.doi.org/10.1002/job.219

Ghozali, I. (2011). Structural equation modeling: Metode alternative dengan partial least square PLS. Badan Penerbit UNDIP. Semarang.

Givens, R. J. (2008). Transformational leadership: The impact on organizational and personal outcomes. Emerg. Leadersh. Journeys, 1, 4-24. Retrieved from http://www.regent.edu/acad/global/publications/elj/ issue1/ELJ_V1Is1_Givens.pdf

Herman, \& Swastika, D. K. S. (2011). [Peningkatan kelompok tani: Langkah awal kesejahteraan petani. Strengthening farmers group: Improving the welfare of farmers first step]. Analisis Kebijakan Pertanian, 9, 371-390. Retrieved from http://pustaka.litbang.deptan.go.id

Howell, J. M., \& Hall-Merenda, K. E. (1999). The ties that bind: The impact of leader-member exchange, transformational and transactional leadership and distance on predicting follower performance. J. Applied 
Psychol., 84, 680-694. http://dx.doi.org/10.1037/0021-9010.84.5.680

IFAD. (2010). Promoting women's leadership in farmers' and rural producers' organizations. Retrieved from http://www.ifad.org/farmer/2010/agenda/e/report_women.pdf

Janssen, O., \& van Yperen, N. W. (2004). Employees' goal orientations, the quality of leader-member exchange and the outcomes of job performance and job satisfaction. Acad. Manage. J., 47, 368-384. http://dx.doi.org/10.2307/20159587

Liden, R. C., \& Maslyn, J. M. (1998). Multidimensionality of leader-member exchange: An empirical assessment through scale development. J. Manage., 24, 43-72.

Ngaruko, D. D., \& Lwezaula, D. D. (2013). Determinants of farmers' group membership satisfaction in Mbozi district, Tanzania: Exploring farmers' opinions. International Journal of Economy, Management and Social Sciencies, 2(11), 919-923. Retrieved from http://waprogramming.com/index.php?action=paper\&jid= 6\&iid $=72 \&$ pid $=429$

Nguni, S., Sleegers, P., \& Denessen, E. (2006). Transformational and transactional leadership effects on teachers' job satisfaction, organizational commitment and organizational citizenship behavior in primary schools: The Tanzanian case. School Effectiveness School Improv., 17, 145-177. http://dx.doi.org/10.1080/09243450600565746

Ofuoku, A. U., \& Agbamu, J. U. (2013). Leadership effectiveness among farmers' self-help groups in central agricultural zone of delta state, Nigeria and its implication for improved agriculture extension service. Asian Journal of Agricultural Extension, Economics and Sociology, 2(1), 41-53. Retrieved from http://www.sciencedomain.org/abstract.php?iid=178\&id=25\&aid=1224\#.UxufwT9dWtZ

Podsakoff, P. M., MacKenzie, S. B., Moorman, R. H., \& Fetter, R. (1990). Transformational leader behaviors and their effects on followers' trust in leader, satisfaction and organizational citizenship behaviors. Leadership Q., 1, 107-142. http://dx.doi.org/10.1016/1048-9843(90)90009-7

Subejo. (2009). Characteristics and functions of labor institutions in rural java: A case study in Yogyakarta Province. J. ISSAAS, 15(1), 101-117. Retrieved from http://www.issaas.org/journal/v15/01/ journal-issaas-v15n1-subejo.pdf

Truckenbrodt, Y. B. (2000). The relationship between leader-member exchange and commitment and organizational citizenship behavior. Acad. Rev. Q. Summer, 1, 233-244. Retrieved from $\mathrm{http}: / /$ citeseerx.ist.psu.edu/viewdoc/download?doi=10.1.1.169.8630\&rep=rep1\&type=pdf

Volmer, J., Niessen, C., Spurk, D., Linz, A., \& Abele, A. E. (2011). Reciprocal relationship between LMX and job satisfaction: A cross-lagged analysis. Applied Psychology: An international review, 60(4), 522-545. http://dx.doi.org/10.1111/j.1464-0597.2011.00446.x

Wahyuni, S. (2003). Kinerja kelompok tani dalam sistem usaha tani padi dan metode pemberdayaannya. $J$. Litbang Pertanian, 22. Retrieved from http://pustaka.litbang.deptan.go.id/publikasi/p3221031.pdf

Wang, H., Law, K. S., Hackett, R. D., Wang, D., \& Chen, Z. X. (2005). Leader-member exchange as a mediator of the relationship between transformational leadership and followers' performance and organizational citizenship behavior. Acad. Manage. J., 48, 420-432. http://dx.doi.org/10.5465/AMJ.2005.17407908

Yunasaf, U. (2007). The leadership of chairman of groups and its association with group effectiveness. Retrieved from http://pustaka.unpad.ac.id/wp-content/uploads/2009/11/kepemimpinan_ketua_kelompok.pdf

\section{Copyrights}

Copyright for this article is retained by the author(s), with first publication rights granted to the journal.

This is an open-access article distributed under the terms and conditions of the Creative Commons Attribution license (http://creativecommons.org/licenses/by/3.0/). 